MISCELLANEA
GEOGRAPHICA

Vol. 13/2008

pp. $153-162$

\begin{abstract}
Barbara Braun
University of Warsaw - Faculty of Geography and Regional Studies - Department of Geoecology 00-927 Warsaw, Krakowskie Przedmieście 30

e-mail: bjbraun@uw.edu.pl
\end{abstract}

\title{
IMPACT OF AGRICULTURAL USE ON CHOSEN SOIL PROPERTIES
}

\begin{abstract}
Agricultural use may change soil. These changes may be observed by examining certain soil properties. In numerous cases of agricultural use, soil compaction may be observed at the depth of 25-35 cm. After many years of use, this may lead to the creation of a plough sole. On arable grounds, which are generally fertilized by minerals, a decrease in organic matter content and soil acidification are frequently observed.
\end{abstract}

Key words: agricultural use, soil reaction, bulk density, organic matter

\section{INTRODUCTION}

Each human activity leads to changes in the natural environment. In the case of agricultural use, the greatest changes take place in soil. Mechanization in agriculture and the wish to produce ever-greater amounts of crops influence changes in some soil properties. In a short time, changes in soil reaction, organic matter content or creation of a plough sole at the depth of 25-35 cm may observed (Stojek 2004; Stojek 2005; Uggla 1976).

\section{RESEARCH SUBJECT, OBJECTIVE AND METHODOLOGY}

The research grounds were located in northern Poland (the Kaszuby Lake District) and in central Poland (the Płock area). Different 
soil types, created by postglacial deposits of the Vistula and Warta Rivers glaciations, were observed. On soil deposits, usually of sandur origin, Podzols originated. Cambisols were created upon argillaceous deposits and sand banks. In addition, Humic Gleysols, Histosols and often, Colluvic Anthrosols may be found in land depressions.

The objective of the research was to determine the impact of agricultural use on chosen soil properties.

At hand were data from the sixties of the $\mathrm{XX}^{\text {th }}$ century for both regions, for the year 2002 for the Płock area and for the year 2006 for the Kaszuby Lake District. The data came from arable land classification statements dating to the sixties and from the Author's own research including the years 2002 and 2006 . The analyses for the years 2002 and 2006 were carried out in about 60 exposures. In the Płock area, 48 exposures were made on about $530 \mathrm{~km}^{2}$. In the Kaszuby Lake District, 12 exposures and 15 drilling holes were made on about $900 \mathrm{~km}^{2}$. Research in the Kaszuby Lake District is being continued.

Common methods for soil examination were applied in the research. The real bulk density was described on the basis of small metal cylinders with a capacity of $100 \mathrm{~cm}^{3}$. Soil samples were dried in the temperature of 105 şC. Samples for the cylinders were collected at each ground horizon and in addition, at the depth of 20-30 cm. Soil reaction in the area was examined by the Hellige $\mathrm{pH}$ metre and in the laboratory by the potentiometer method. The organic matter content was determined by the Tiurin method.

\section{RESULTS AND DISCUSSION}

Soil bulk density and soil compaction at the depth of $25-35 \mathrm{~cm}$ are properties well illustrating the impact of mechanization on agriculture. The bulk density value for the examined soils fluctuated between $1,1-1,4 \mathrm{Mg}^{*} \mathrm{~m}^{-3}$ for sandy soils and $1,7-1,9 \mathrm{Mg}^{*} \mathrm{~m}^{-3}$ for clay soil (Tab. 1). It turned out that parent rock does not have significant impact on soil density at the depth of $25-35 \mathrm{~cm}$. It was also observed that the bulk density values for soils created by the Vistula and Warta Rivers glaciations were similar.

Research in northern Poland (the Kaszuby Lake District) as well as in central Poland (the Płock area) showed soil bulk density at the depth of 25-35 cm. In relationship to the layer situated above the soil 
compaction horizon, bulk density values differed by $0,05-0,2 \mathrm{Mg}^{*} \mathrm{~m}^{-3}$ (Fig. 1-3). It is possible to assume that in the future a plough sole will be created which will undoubtedly result in an improper water flow into the soil profile and unsuiTable aeration of the humus horizon.

Tab. 1.

Range of bulk density values of the sTable stage in surface and subsurface layers in northern and central Poland

\begin{tabular}{|c|c|c|}
\hline Granulometric soil composition & Depth $(\mathrm{cm})$ & Bulk density $\left(\mathrm{Mg}^{*} \mathrm{~m}-3\right)$ \\
\hline sand deposits & $10-15 \mathrm{~cm}$ & $1,2-1,7$ \\
& $25-35$ & $1,4-1,7$ \\
\hline clay deposits & $10-15 \mathrm{~cm}$ & $1,4-1,7$ \\
& $25-35$ & $1,5-1,8$ \\
\hline silit deposits & $10-15 \mathrm{~cm}$ & $1,1-1,6$ \\
& $25-35$ & $1,5-1,6$ \\
\hline
\end{tabular}

Source: own elaboration.

Most often, compaction of the subarable horizon takes place in soils made up of sand deposits, rarely in silit and clay deposits (Fig. 1-3). The soil type being used also has impact on the degree of compaction of the subarable horizon. The classical cultivation method, i.e. based on the plough system, guarantees soil loosening in the surface horizon and compaction at the depth of 25-35 cm (Fig. 1, 3) (Stojek 2004; Włodek et al. 1998). While applying simplified methods, most often without ploughing prior to sowing, both the humus and subsoil horizons undergo compaction (Białczyk et al. 2000). Soil compaction from the surface has been observed on grounds used as meadows (Fig. 4). This is the result of farm machinery crossing and not of surface layer loosening. Additionally, meadows belong to soils with increased organic matter content. Significant share of meadows has been reclaimed which results in mineralization of organic matter and compaction of the surface horizon (Stojek 2005).

Soil reaction is an easily tested property. Reaction is one of the sensitive change indicators. Due to it, even a few years' changes may be observed, especially those which are a consequence of human activity (Stojek 2005). Together with a change in reaction, changes occur in the assimilability of micronutrients and some macronutrients as well. Thus, biological and physical soil properties change (Gorlach, Mazur 2001). 


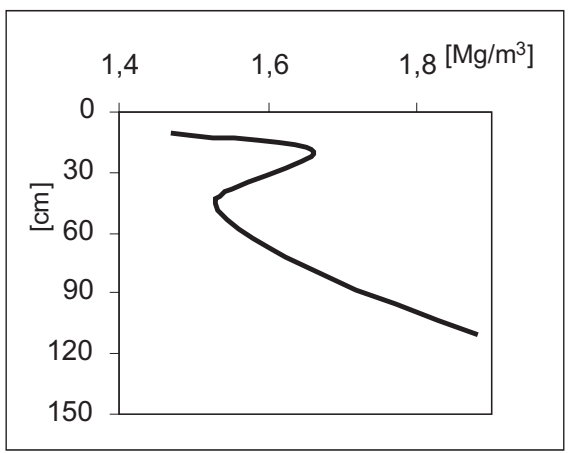

Fig. 1. Bulk density of soil made up of loamy sand (arable land)

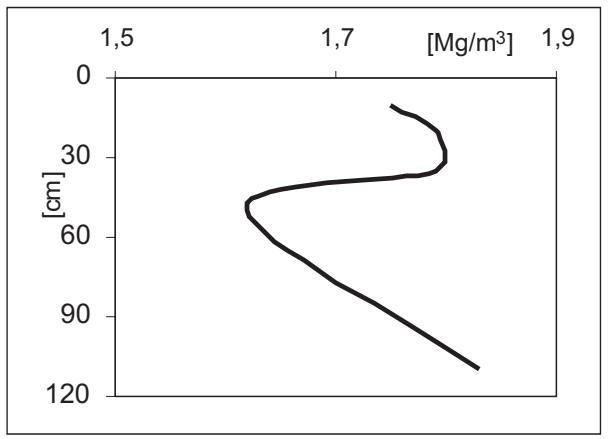

Fig. 3. Bulk density of soil made up of sandy loam (arable land)

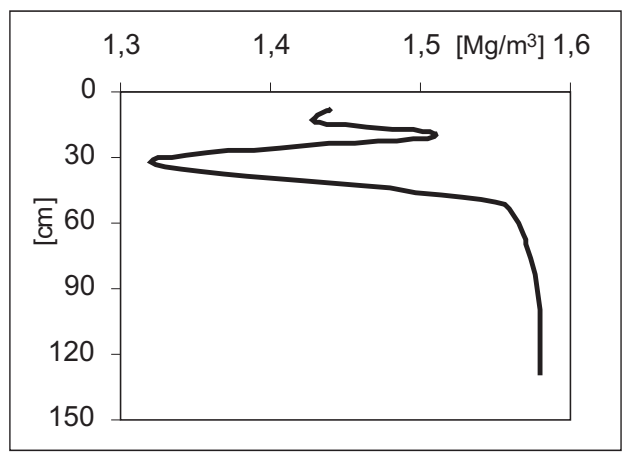

Fig. 2. Bulk density of soil made up of sand (arable land)

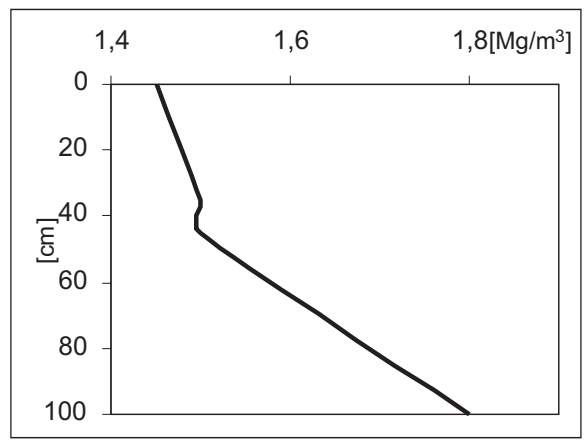

Fig. 4. Bulk density of soil made up of clay loam (meadow)

Source: own elaboration.

Soils with acid and semi-acid reactions dominate in northern and central Poland. Soils with a neutral $\mathrm{pH}$ may be found rarely (Tab. 2, 3).

Most often, in the total profile, Podzols have an acid reaction. On the other hand, Cambisols, Humic Gleysols, Histosols and Colluvic Anthrosols have a more diversified reaction, i.e. from acid in the surface horizon to neutral in the parent rock.

In the sixth decade of the XXth century, at both observation areas, Cambisols and Luvisols were characterized by $\mathrm{pH} 4,4-6,0$. Thus, we include them in the acid soil category (Fig. 5, 6). On the other hand, in 2002-2006, the $\mathrm{pH}$ fluctuated between $3,0-7,0$ (Tab. 2, 3). In the 
Kaszuby Lake District, in the sixties, soil used by individual farmers was characterized by greater acidity, e.g. exploration wall 2, Fig. 5. Their $\mathrm{pH}$ values are about 5 . Next, soils being used by the National Land Holdings were most often characterized by a higher $\mathrm{pH}$ of about 6 , e.g. exploration walls 1,5 , Fig. 5 . It may be assumed that in the sixties lime was applied to these soils. Currently, these grounds are also used by individual farmers. They are characterized by a somewhat higher $\mathrm{pH}$ level on the humus horizon and lower on the subsurface horizon than in the sixties (exploration wall 5). On the basis of interviews which were carried out, it may be deduced that immediately following lease of theses soils, lime was applied to majority of them. On the other hand, throughout the forty-year period of observation, Cambisols which throughout this time were the property of individual farmers are characterized by a stable reaction at about $\mathrm{pH} 5$.

Tab. 2.

Value range of reaction and organic matter in soils of central Poland in 1960 and 2000

\begin{tabular}{|c|c|c|c|c|}
\hline \multirow{2}{*}{ Soil type } & Genetic horizon & \multicolumn{2}{|c|}{$\begin{array}{c}\text { Reaction } \\
(\mathrm{pH})\end{array}$} & $\begin{array}{c}\text { Corg } \\
(\%)\end{array}$ \\
& & 1960 & 2002 & 2002 \\
\hline \multirow{3}{*}{ Cambisols } & A & $5,0-7,0$ & $3,0-7,0$ & $0,8-1,9$ \\
& Bbr & $5,0-6,5$ & $4,4-7,0$ & \\
& C & $5,5-7,0$ & $5,2-7,2$ & \\
\hline \multirow{2}{*}{ Luvisols } & A & $4,4-6,0$ & $4,0-6,0$ & $0,8-1,4$ \\
& Eet & $5,0-6,0$ & $4,0-5,5$ & \\
& Bt & $5,0-6,0$ & $4,8-6,0$ & \\
Brunic Arenosols & C & $5,0-7,0$ & $5,0-6,0$ & \\
& A & $4,5-5,0$ & $2,8-4,3$ & $0,4-1,7$ \\
& Bv & $4,5-5,5$ & $3,6-5,3$ & \\
& C & $4,0-6,0$ & $3,7-6,6$ & \\
\hline \multirow{2}{*}{ Humic Gleysols } & A & $5,5-6,5$ & $4,2-7,1$ & $1,5-4,1$ \\
& AC & $5,5-6,5$ & $5,0-7,0$ & \\
\hline \multirow{2}{*}{ Histosols and Drainic Histosols } & CG & $5,0-7,0$ & $5,5-7,7$ & \\
& PO (M) & $5,5-6,5$ & $7,8-7,3$ & $54-79$ \\
& T & $5,5-6,5$ & $5,5-7,0$ & \\
\hline
\end{tabular}

Source: own elaboration. Data from the sixties come from arable land classification statements 
Tab. 3.

Value range of reaction in soils in northern Poland in 1960 and 2006

\begin{tabular}{|c|c|c|c|}
\hline \multirow{2}{*}{ Soil type } & Genetic & \multicolumn{2}{|c|}{ Reaction } \\
& horizon & 1960 & 2006 \\
\hline \multirow{3}{*}{ Cambisols } & A & $5,0-6,0$ & $5,0-6,5$ \\
& Bbr & $5,0-7,0$ & $5,0-6,5$ \\
& C & $5,5-7,0$ & $5,5-7,0$ \\
\hline \multirow{3}{*}{ Luvisols } & A & $4,5-6,0$ & $5,5-6,0$ \\
& Eet & $4,5-6,0$ & $5,0-6,5$ \\
& Bt & $5,0-6,0$ & $5,5-6,5$ \\
& C & $5,0-6,0$ & $5,5-7,0$ \\
\hline \multirow{2}{*}{ Brunic Arenosols } & A & $4,5-5,5$ & $5,0-6,5$ \\
& Bv & $4,0-5,0$ & $5,0-6,5$ \\
& C & $5,0-5,5$ & $5,5-7,0$ \\
\hline
\end{tabular}

Source: own elaboration. Data from the sixties come from arable land classification statements

In the Cambisols and Luvisols of central Poland, throughout the forty-year period, an advanced acidification process was observed, e.g. exposure walls 1, 2, Fig. 6. A decrease in the $\mathrm{pH}$ of the humus horizon usually amounted to $1.2-1.5$ units. In the subsurface horizon, fluctuation of reaction are small or do not occur at all.

In both of the examined areas, Brunic Arenosols were and still are most often used by individual farmers. Their reaction level is somewhat different. In the sixties, the $\mathrm{pH}$ level fluctuated between 5 in the humus horizon to 6 in the parent rock (Fig. 5, 6). However, in 2006, the $\mathrm{pH}$ level in the humus horizon remained at the level of the sixties or slightly increased, e.g. exposure wall 3, Fig. 5). On the basis of interviews which were carried out, it may be surmised that lime is applied to these grounds on a regular basis. This is not always favourable to Podzols and Brunic Arenosols. On rare occasions, a decrease in the $\mathrm{pH}$ value was observed in rusty soils, e.g. exposure wall 3, Fig. 6.

On soils which were set aside for wastelands, it was noted that the humus horizon was enriched by acid cations which illustrates the acidification process of these soils. This occurs, above all, in soils created by sandy deposits, e.g. exposure walls 3, 4, Fig.6.

In northern Poland, in undulating areas, there are Colluvic Anthrosols. Their reaction, e.g. exposure wall 4, on the humus horizon, in the sixties as well as currently, is acid ( $\mathrm{pH}$ about 5, Fig. 5). However, on the 
subsurface horizons, $\mathrm{pH}$ is somewhat higher, even though it decreased during the last forty years. It may be assumed that the subsurface alluvial horizons are richer in nutrients than the surface horizons.

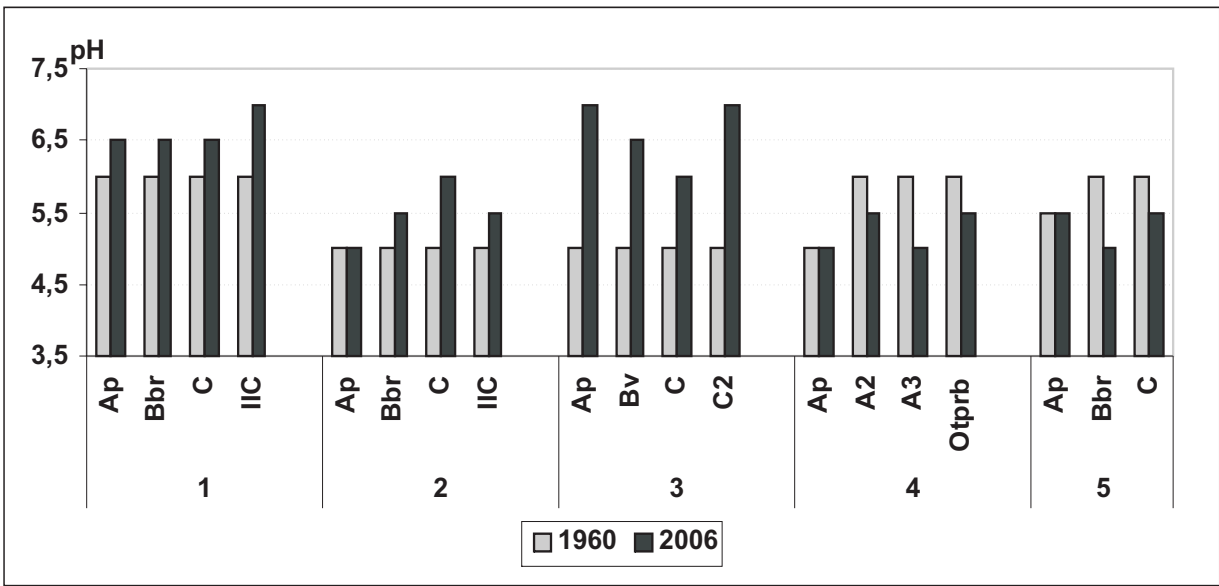

Fig. 5. Soil reaction in northern Poland in 1960-2006

Source: own elaboration

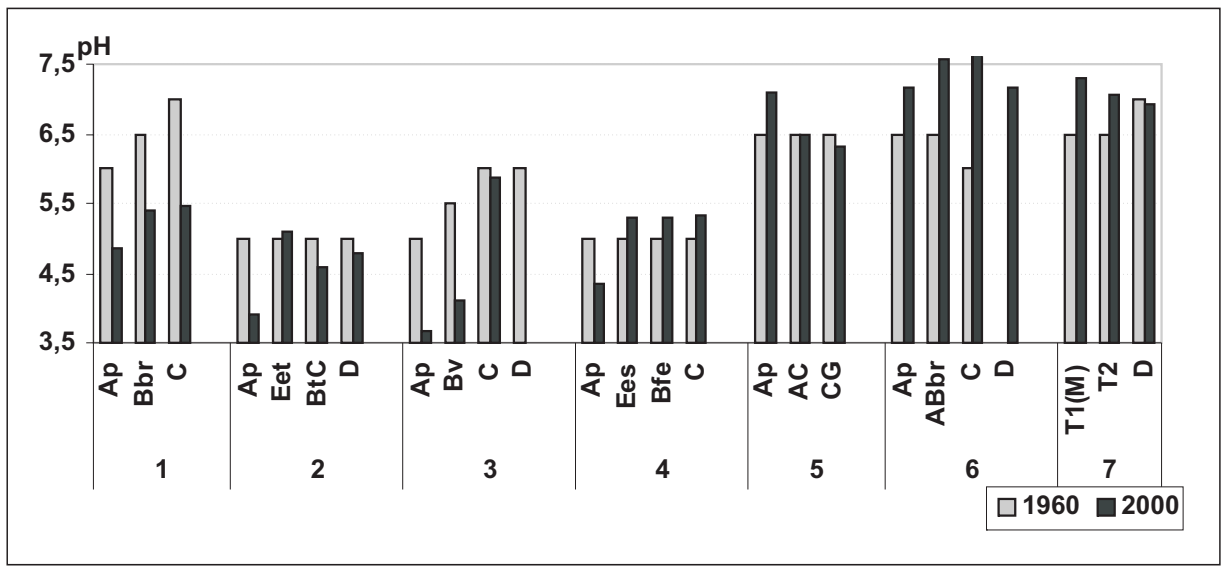

Fig. 6. Soil reaction in central Poland in 1960-2006

Source: own elaboration

In the forty-year period, Humic Gleysols, Colluvic Anthrosols and Histosols are characterized by the most stable reaction, even though in certain profiles of these soils, a decrease of o $0.4-0.8$ units was reported 
(Fig. 6). In general, such soil reaction developed on the slightly acid to neutral levels (Tab. 2). Such a stability of reaction was guaranteed by organic matter content which has good sorption properties, in the direction of alkaline cations.

An interesting phenomenon, confirmed in undulating and hilly terrain in northern Poland, is the difference of reaction on the humus horizon between the summit, slope and foot slope (Fig. 7). Soils show a somewhat more acidy reaction on summits than on slopes and foot slopes. This is due to the flow of mineral elements together with humus down the stock (Lecomte, Le Bissonais 1999). Surface layers, however, are characterized by a more balanced reaction throughout the total length of a slope. This has been proven in 7 samples and will continue to be examined in diversified terrain.

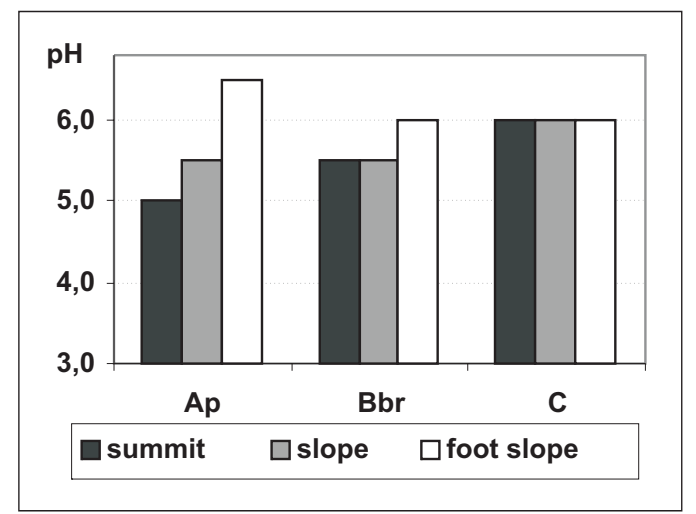

Fig. 7. Changes in soil reaction in the peak-slope-slope-foot arrangement. Source: own elaboration.

Intensive agricultural use leads to diminishment of organic matter content in soils (Acton, Gregorich 1995; Gorlach, Mazur 2001). The greatest dynamics of diminishment of organic matter content in Histosols, Drainic Histosols and Humic Gleysols, i.e. in soils which are the richest in organic matter (Tab. 2). In organic soils a decrease in the amount of organic matter content is caused by land melioration and crop (grasses) sprawl beyond the field. However, diminishment of humus in Humic Gleysols is caused by agrotechnical measures and intense fertilization, including liming (Karlik 1997; Stojek 2005). In other soils, depletion of organic matter is smaller (Stojek 2005). Even 
a small increase in organic matter content took place in soils where use was changed from crop production to meadows or in soils which are lying fallow. The phenomenon of enrichment by humus was reported in soils rich in organic matter, e.g. Humic Gleysols, and in those with limited organic matter, e.g. Brunic Arenosols. A similar trend was observed by Eve et al. (2002) and Lala et al. (1999).

\section{CONCLUSION}

1. Mechanical use of arable land leads to the creation of a compacted layer at the depth of $25-35 \mathrm{~cm}$. Compaction of subsoil is, at maximum, greater by $0,2 \mathrm{Mg}^{*} \mathrm{~m}^{-3}$, than of the horizon located above the compacted layer. The greatest compaction takes place in soils created from sand deposits.

2. In the Płock area soils, a progressive acidification process was reported, especially in Cambisols and Luvisols. No large reaction fluctuations were reported in most of the soils examined in the Kaszuby Lake District. It may be assumed that these soils were and regularly are limed in optimal doses for the given soil type, which results in maintaining the reaction on the proper level. Individual use or management by national holdings did not have impact on the difference in reaction.

3 . On the humus horizon, a difference in reaction was observed between the summit, slope and foot slope in terrain with diversified sculpture. On the summit, soils showed a somewhat more acid reaction than on the slope and the foot slope.

4. In many circumstances, location at the foot slope is favourable to deepening the humus horizon and to the creation of alluvial soils. Most often, the reaction of subsequent alluvial soil horizons approximates reaction of humus soil located on the summit and slope.

5. Intensive mechanical cultivation generates diminishment of organic master content in the humus horizon. The greatest decrease was noted in soils rich in organic matter, that is Histosols, Drainic Histosols and Humic Gleysols. Additionally, even a small increase in the organic matter content was observed in meadow wasteland soils. 


\section{REFERENCES}

Acton D.F., Gregorich L.J., 1995, The health of our soils, towards the sustainable agriculture in Canada. Agriculture and Agri-Food Canada, Research Branch. Center for Land and Biological Resources Publ.

Białczyk W., Czarnecki J., Kordas L., Pieczarka K., 2000, Zmiany niektórych właściwości fizycznych i mechanicznych gleby w różnych technologiach uprawy [Changes in some physical and mechanical properties of soil in different cultivation technologies; in Polish], Inżynieria Rolnicza, 6: 47-53.

Eve M.D, Sperow M., Paustian K., Follett R.F., 2002, National-scale estimation of changes in soil carbon stocks on agricultural lands, Environmental Pollution, 116: 431-438.

Gorlach E., Mazur T., 2001, Chemia rolna [Agricultural chemistry; in Polish], Wydawnictwo Naukowe PWN, Warszawa.

Karlik B., 1997, Wymywanie materii organicznej z gleb [Washing out organic matter from soil; in Polish]. Rozprawy Naukowe. Roczniki Akademii Rolniczej, Poznań, 277: 5-66.

Lal R., Follett R.F., Kimble J.M., Cole V.R., 1999, Managing U.S. cropland to sequester carbon in soil, J. Soil Water Cons., 54: 374-381.

Lecomte V., Le Bissonais Y., 1999, Transfer de pesticides par ruissellement et l'érosion de la parcelle au bassin versant, dans la région agricole du Pays de Caux. [in:] Paysages agraires et Environnement. CNRS, Paris: 239-251.

Stojek B., 2004, Plough Sole as the Result of the Agricultural Land Use. Miscellanea Geographica, Warszawa, 11: 63-69.

Stojek B., 2005, Zmiany właściwości chemicznych i fizykochemicznych w glebach użytkowanych rolniczo [Changes in chemical and physiochemical properties in soils used in agriculture; in Polish] [in:] Zintegrowane badania krajobrazowe i ich zastosowania, Prace $i$ Studia Geogr., Warszawa, 36: 97-106.

Uggla H., 1976, Gleboznawstwo rolnicze [Agricultural soil science; in Polish]. PWN, Warszawa: 224-231.

Włodek S., Kukuła S., Pabin J., Biskupski A., Kaus A., 1998, Zmiany gęstości, zwięzłości i wilgotności gleby powodowane różnymi sposobami uprawy rol [Changes in soil compaction, cohesion and humidity generated by diverse cultivation methods; in Polish]. Zesz. Probl. Post. Nauk Rol., 460: 413-420. 